\title{
RigHTS AND CITIZENSHIP IN THE EUROPEAN UNION
}

\author{
DENNIS C. MUELLER
}

CESIFO WORKING PAPER NO. 896

CATEGORY 2: PuBlic CHOICE

MARCH 2003

PRESENTED AT CESifo CONFERENCE “ A CONSTITUTION FOR THE EUROPEAN UNION”, FEBRUARY 2003

\footnotetext{
An electronic version of the paper may be downloaded

- from the SSRN website: www.SSRN.com

- from the CESifo website: www.CESifo.de
} 


\title{
RIGHTS AND CITIZENSHIP IN THE EUROPEAN UNION
}

\begin{abstract}
This paper employs the methodology of "constitutional political economy" to examine the definition of citizenship, and the delineation of the rights that accompany citizenship. The concepts developed are then applied to the question of how rights and citizenship should be defined in the European Union. The answer to this question is shown to depend on whether the Union is organized as a federation or a confederation. The concepts developed are then used to critique the Charter of Fundamental Rights of the European Union, and to question whether this Charter should be made a part of a new European Union constitution.
\end{abstract}

JEL Code: D71, D72.

Dennis C. Mueller

Department of Economics

University of Vienna

BWZ - Bruenner Str. 72

A- 1210 Vienna

Austria

Dennis.Mueller@univie.ac.at 
Two of the fundamental elements of any constitution are the definition of citizenship for the polity, and the delineation of the set of rights that accompany citizenship. These are separate questions, although as we shall see, they raise similar issues, and thus will be treated jointly in this essay. The approach taken will be that of what has come to be called “constitutional political economy." Namely, I shall analyze the properties of rights and citizenship in the context of a society of rational, self-interested individuals who define a set of rights and criteria for citizenship as part of a constitution written to advance their collective interests. The society in question in this case is the European Union, and so the approach envisages an assembly of representatives of Europeans from the current EU countries meeting to write a new constitution to govern their collective lives.

The nature of the questions addressed is such that there is no "bottom line" in the sense of a list of specific rights and a definition of citizenship, which appear at the end of the essay. The goal is rather to identify the salient properties of rights and citizenship to serve as a guide to a constitutional assembly, which would in fact have to make up such a list and define the criteria for citizenship. An important contribution of the essay is to highlight the relationship between the structure of the European Union, in particular whether it is organized as a federation or a confederation, and the characteristics of the set of rights and definition of citizenship that should be chosen.

Sections I and II are concerned with the definition of citizenship. Here the focus is on the right or privilege of voting. What criteria should a constitution establish for allowing a person to vote? Section I takes up the question in the abstract, Section II discusses the issue in the context of the EU. 
Sections III and IV are concerned with rights. Once again the first of these examines the general characteristics of rights, the second applies the analysis to the EU. In Section V the concept of rights presented here is used to discuss some of the issues raised by the Convention for the Protection of Human Rights and Fundamental Freedoms and the Charter of Fundamental Rights of the European Union. The final section of the paper draws some conclusions, and discusses the relevance of the discussion for the deliberations of the constitutional convention currently taking place, and for future constitution writing in the EU.

\section{Defining Citizenship ${ }^{1}$}

To begin, let us imagine a group of people living on Utopia, an isolated island in the Blissful Ocean. They have decided to create a state. The potential set of citizens is thus easily identified as all individuals currently living on the island.

\section{A. Optimal Citizenship with Homogeneous Preferences}

Consider first the case in which every individual on the island has the same preference function and income. The purpose in forming a state is to provide a single, lumpy public good, $G$. Since all potential citizens have the same preference functions, they realize that the optimal provision of the public good will involve equal tax shares. In the absence of crowding, each citizen's share of the public good's cost falls as the size of the polity increases, and its optimal size is infinity. Utopia is a small island, however, and therefore the possibility of crowding must be taken into account. Let each citizen's utility, $U$, be written as a function of her private good consumption, $X$, the public good, and the size of the polity, $n$.

$$
U=U(X, G, n)
$$


Since all individuals pay the same fraction of the public good's costs, we can define the prices of the public and private good to make $X=G / n$. Using this expression to replace $X$ in (1) and maximizing with respect to $n$ and $G$ yields

$$
\frac{1}{n} \frac{\partial U}{\partial G}=-\frac{\partial U}{\partial n}
$$

Utopians maximize their expected utilities by limiting the population's size so that the marginal gain from adding another person to the island in terms of a reduced share of the public good's cost just equals the marginal cost from increased crowding caused by this person.

If the $n$ satisfying (2) is less than the population of the island, then the task of individuals at the constitutional stage is simple. All current residents are made citizens. Moreover, it will be in the interests of the current residents to allow immigration up until the optimal-sized community is reached. The situation is potentially more complicated, when the optimal population size for Utopia is less than its current level.

One possibility here would be to make all current residents citizens, and allow free emigration. If other islands like Utopia exist upon which the population size is less than optimal, Utopians will have an incentive to migrate to them up until the point where the population of Utopia is optimal.

A second possibility is that no such attractive options for emigration exist. Utopians will then have no other option than to make everyone a citizen, prohibit immigration, and perhaps take additional steps to reduce the population of Utopia by discouraging births or encouraging emigration. 


\section{B. Optimal Citizenship with Heterogeneous Preferences}

Consider now the consequences of citizens having different preferences. Let there be two groups, the Blues and the Greens. The sole public good to be provided is a highway across the island, whose cost will be shared equally by members of both groups. It is technologically infeasible once the highway is built to prevent members of either group from using it. Blues favor a high quality, four-lane highway, which will allow high-speed driving with minimal delays. Greens favor a low quality, two-lane highway, which will cause lowspeed driving with many delays. Looking forward into the post-constitutional stage both groups can see that if everyone on the island is made a citizen, the outcome of the political process will be a compromise in which some parts of the highway have four lanes, and other parts only two. Both groups can expect higher utilities if they are free to construct the highway as they prefer. It will not make sense for the Greens to construct a two-lane highway alongside of a four-lane one. Knowing this, the Blues have an incentive to form the state by themselves, that is to define citizenship for Blues only, and build a four-lane highway. This is obviously true if individuals at the constitutional stage know whether they will be Blues or Greens in the post-constitutional stage. But it is also possible that all Utopians unanimously agree to form a state in which only Blues have citizenship from behind the veil of ignorance. A sufficient condition for such a unanimous agreement would be, for example, that the Blues be in the majority and the utility gain for each Blue from choosing the type of highway equals the loss to each Green. ${ }^{2}$

If the Blues are in the majority they could achieve the same outcome by granting Greens citizenship, and simultaneously selecting the simple majority rule as the voting rule to be used for making collective decisions in the post-constitutional stage. Here we have reached an important result. For the majority group, the definition of citizenship and the 
choice of voting rule may be substitutes. A group with an absolute majority of the population can ensure that it dictates all outcomes in the post-constitutional stage either by excluding members of the other group(s) from citizenship, or by choosing a voting rule requiring a majority below that which they have, as say, a simple majority. Buchanan and Tullock (1962) introduced the concept of external costs of collective decision making and used it to define the optimal voting rule from the point of view of citizens at the constitutional stage. In our example, inclusion of the Greens in the collective decision process creates a negative externality for the Blues, an externality that they can eliminate either by excluding the Greens from the collective decisionmaking process entirely, or by effectively excluding them through the choice of a voting rule.

The same two options do not exist for a minority group. If the Greens constitute 35 percent of the population, they cannot dictate outcomes in the post-constitutional stage by choosing a one-third majority rule at the constitutional stage, for the Blues would easily satisfy this requirement. The Greens can ensure that their most-preferred options win only by creating a state in which only they have the right to decide for the combined community. ${ }^{3}$

Although limiting citizenship to only certain groups is a possible outcome of the constitutional process, when individuals have heterogeneous preferences, it is of course not an inevitable one. The possibility exists that both groups obtain citizenship and compromises emerge out of post-constitutional politics, when individuals define citizenship from behind the veil of ignorance. The likelihood of this happening increases if we expand the number of post-constitutional collective choices and allow for more groups, so that every group has a chance of being part of the majority on some future issues. Although such assumptions increase the likelihood of inclusive definitions of citizenship, they do not guarantee it, when individuals choose definitions of citizenship that maximize their expected utility. With 
sufficient preference heterogeneity, the expected utility of an individual at the constitutional stage will be maximized - even from behind the veil of ignorance - by excluding some groups from affecting future collective choices. This can always be accomplished by excluding these groups from citizenship. When these groups constitute a minority of the population, they can be effectively excluded even when granted citizenship, by choosing the simple majority rule as the community's voting rule.

\section{Optimal Citizenship with Heterogeneous Preferences and Separated Communities}

Imagine now a second island, Polyana, not too far from Utopia. All Utopians have identical preferences for public and private goods as do all Polyanians, but the preferences of the two groups differ from one another. In addition to the public goods that each island can supply to itself, a set of public goods exists that could benefit both islands, if jointly supplied to them. The citizens of both islands contemplate forming a larger polity - the United Islands - to provide the public goods that would benefit both.

Obviously both Utopians and Polyanians will have to be citizens in this new polity if it forms. Neither group would agree to join a community in which they were obligated to pay taxes for a public good, but were denied the opportunity to help determine its quantity and their tax shares. If the United Islands comes into existence both groups will have to have citizenship and be represented in the assembly that makes decisions for the new polity.

Equally obviously, the voting rule used in this assembly cannot be the simple majority rule. If the assembly were formed by parties competing for votes across the two islands, and seats in the assembly were allocated according to the number of votes each party received, then two parties would take seats in the assembly - a Utopian Party and a Polyanian Party. If Utopia had the largest population, it would win a majority of seats in the assembly 
and could dictate the choice of public goods and tax shares under the simple majority rule. Citizens on Polyana would never agree to the use of the simple majority rule in the assembly, if they wished to maximize their expected gains from membership in the new state. If Utopia has $\alpha$ fraction of the population of the two islands, then any voting rule requiring more than $\alpha$ fraction of the votes in the assembly would require an agreement between both parties to reach a decision. De facto such a voting rule would be equivalent to the unanimity rule, and it would cost the two islands nothing as against requiring a majority greater than $\alpha$, if they wrote this voting rule into their constitutions.

With all citizens of Utopia having identical preferences, they could be optimally represented by sending a single person to the representative assembly, as could all Polyanians under the assumption that they have homogeneous preferences. In this situation, the new state could be optimally constituted as a confederation of the two island communities with the elected governments of each island sending delegations to an assembly that would make decisions for the greater polity under the unanimity rule.

As noted, the citizens of either island would only agree to join the larger polity if they were granted citizenship in it. What citizenship rights should exist in this new polity with respect to the two island polities? If a Polyanian migrates to Utopia should she both retain her citizenship in the United Islands and be able to take up citizenship and vote in Utopia?

Under the assumptions that we have made about the preferences of the two groups, the answer to this question is not necessarily yes. If migrants from the other island are allowed to vote in local elections, and their votes affect the collective decisions made, costs will be imposed on the island receiving migrants. There may also be offsetting benefits, of course, as for example, if an island's population is less than optimal size. But, when a confederation is the optimal political structure for joining groups of geographically separated 
people with heterogeneous preferences, the presumption must be that migration will entail costs, and each lower level polity may find it optimal to minimize these costs by not granting migrants from other parts of the confederation voting rights in their polity.

\section{Optimal Citizenship with Dispersed Populations and Heterogeneous Preferences}

Imagine now that Polyana and Utopia both contain mixtures of Blues and Greens, with each group as before having identical preferences that differ from those of the other group. Now it would not be possible to select a single person from one island who could accurately represent all of its citizens, and a confederation of the two islands may also no longer be optimal. If the government of Utopia is controlled by the Blues, then they would presumably send a delegation to the United Islands' assembly that only represented Blues. The Greens on Utopia would be unrepresented in the larger polity. In this situation having parties compete for votes across the two islands should produce an assembly in which the Greens and Blues would be represented in proportion to their numbers on the two islands.

Assuming that there are some public goods that benefit only the residents on a single island, a federalist political structure is likely to be optimal in this situation. Each island's government makes collective decisions for the island's residents, and an assembly representing citizens across the two islands makes decisions for the larger polity. In such a federalist system, the presumption would be in favor of allowing migrants to take up full citizenship on either island if they move, since Blues and Greens are found on both islands and each must have chosen political institutions to accommodate this heterogeneity. 


\section{Citizenship in the European Union}

\section{A. The Costs of Under- and Overcrowding}

The costs of under- and overcrowding must be viewed in two contexts: (1) migration into and out of the EU, and (2) migration within the EU.

The prognosis for all EU countries is for steadily aging and declining populations. Immigration is one possible way to partly offset the negative effects of these demographic changes. Thinking only in terms of population size would suggest that the EU adopt a fairly liberal policy with respect to allowing immigration and granting citizenship. ${ }^{4}$ Indeed, when one only contemplates the demographics, one might entertain the notion of introducing policies that discourage emigration, particularly by young people. Such policies do not directly raise issues of citizenship, however, but fall rather under the heading of rights.

A knottier question is raised by migration within the EU. A resident of $A$ who contemplates moving to $B$ considers only her expected future utility levels in the two communities. If she acts rationally and selfishly, she ignores any externalities caused by her migration. A consequence of this is that communities, which are particularly attractive places to live and work are likely to attract more than the optimal number of migrants, unattractive communities are likely to suffer from excessive emigration. These problems raise questions both with respect to the rights of citizens to freely move about, and with respect to citizenship itself.

The nature of these questions can be seen by considering the following questions. Who owns the Riviera? All Europeans? The French and Italians? Only those holding property there?

One might argue that it belongs to everyone in Europe, on the grounds that one's place of birth is determined by chance, and someone lucky enough to be born in southern 
France has no more right to the Riviera than someone born on a remote island off the coast of Scotland. To argue otherwise would be to say that the Scot is condemned by birth to a life of toil and hardship, while the Frenchman is entitled to a life of comparative bliss. Accepting the proposition that the Riviera belongs to all Europeans would not imply, however, that all Europeans can move to the Riviera. The costs of congestion remain and an optimal set of policies is going to include measures that discourage people from migrating from Scotland to the Riviera. Claiming that the Riviera belongs to all Europeans will affect the nature of these policies, however. If every European has an equal claim to utility arising from one's place of residence, then the optimal policies to discourage excess migration to the Riviera will involve taxes on those living on the Riviera and perhaps subsidies to those living in places like northern Scotland.

If, on the other hand, the Riviera belongs to those who are now there, then the optimal set of policies to discourage immigration will involve taxes on the migrants. Current residents are then entitled to permanently higher welfare levels than people born into less attractive environments. ${ }^{5}$

Does a person born and raised in Venice think of herself first of all as a Venetian, as an Italian, or as a European? If one of the former, she is probably going to feel that she is entitled to introduce taxes and regulations that "keep Venice for the Venetians." More generally, the answers to these questions have implications for how readily people should be allowed to take up residence and citizenship within the European Union.

\section{B. The Costs of Heterogeneity}

The EU has been created and evolved as a result of a series of agreements among representatives of the member countries. Its history has been one of a confederation, 
therefore, and it operates today more as a confederation than as a federation. The major decisions regarding EU expansion, the Common Agricultural Policy (CAP), and so on are made by representatives of the current governments of the EU members, as befits a confederation. If we are to assume that this political structure is the optimal one for the EU, then it follows from the discussion of the previous section that the preferences of EU citizens must be homogeneous with respect to EU-wide policies within a given country and heterogeneous across them. ${ }^{6}$ With such a distribution of preferences, there are likely to be substantial costs from the migration of individuals across countries, if migrants are allowed to take up citizenship fairly soon after arriving in a different country. By extension, serious costs would be imposed on citizens of the current member countries, if the citizens of new entrants into the EU were allowed to freely migrate into existing member countries and to take up citizenship there.

These considerations imply that the provisions regarding citizenship in the Draft of Article 7 of the Constitutional Treaty ${ }^{7}$ could impose costs on member countries. The second entry of Article 7 reads

Citizens of the Union shall enjoy ... the right to move and reside freely within the territory of the Member States; [and] the right to vote and to stand as a candidate ... in municipal elections in their Member State of residence under the same conditions as nationals of that State.

If the Union's optimal structure is that of a confederation, then allowing immigrants from other EU countries to vote in municipal elections would increase the heterogeneity of the electorate in these elections, worsening the outcomes for local citizens. The force of this provision is, of course, reduced by limiting it to municipal elections, since in most member countries municipal elections are of little consequence, but one expects that the Article would eventually lead to voting rights at the national level in their country of residence for all EU citizens. 
On the other hand, it might be the case that preferences are heterogeneous regarding EU-wide policies within each country. People opposed to the CAP exist in every country, as do its supporters. An advocate of a strong EU-foreign policy is as likely to be found in Denmark as in Portugal. If this assumption more accurately describes the distribution of preferences regarding EU-wide policies, then the free migration of individuals may actually improve political outcomes at the national and local levels of government by allowing individuals to resort themselves into communities of more homogeneous tastes. ${ }^{8}$ A second implication of such a distribution of individual preferences would be that the EU's decisionmaking structure is poorly designed. Decision-making power should reside with the European Parliament not the Council or Commission, and the Parliament's membership should be determined in elections across the entire EU and not just within each member country. ${ }^{9}$ Thus, we conclude that the assumptions one makes about the distribution of preferences across the EU have important implications for both the definitions of citizenship within each country and whether the EU would be best structured as a federation or a confederation.

\section{The Nature of Constitutional Rights}

Among the many elements that must go into a constitution is a voting rule to be used for making future collective decisions. Although the unanimity rule would ensure that no future collective action would harm any citizen, the decision-making costs associated with it argue against it. Some qualified majority rule of less than unanimity is likely to be optimal for many decisions.

Now consider the decision calculus of an individual at the constitutional convention. She must look into the future and envisage all of the possible issues that might come up and 
then decide on the optimal voting rule for each. Given the uncertainties at the constitutional stage this is an impossible task. It is, however, reasonable to assume that an individual at the constitutional stage can envisage broad categories of issues and choose a voting rule for deciding these. On any particular issue, a citizen will be on either the winning or the losing side. Let $s$ be her gain if she is on the winning side, and $u(s)$ her utility from this gain. Let $t$ be her loss if she is on the losing side, and $v(t)$ her utility loss. The probability that she is on the winning side, $p(m)$, is an increasing function of the required majority to pass an issue, $m$, reaching a maximum of 1.0 under the unanimity rule. ${ }^{10}$ An individual at the constitutional stage would then maximize her expected utility by balancing the gains from increasing the required majority and thus her chances of being on the winning side of an issue against the increased decision-making costs accompanying a rise in $m$. It is reasonable to assume that these decision-making costs, $d(m)$, not only increase with $m$, but increase at an increasing rate $\left(d^{\prime}(m)>0\right.$, and $\left.d^{\prime \prime}(m)>0\right)$. An individual's expected gain from a future collective decision can then be written as

$$
G=p(m) u(s)-[1-p(m)] v(t)-d(m)
$$

Maximizing (3) with respect to $m$ yields

$$
p^{\prime}(\mathrm{m})[u(s)+v(\mathrm{t})]=d^{\prime}(m)
$$

as a first-order condition. The left-hand-side of (4) is the marginal gain from increasing the required majority and thereby reducing the chance of being on the losing side, the right-handside is the marginal cost of increasing $m$ and thereby increasing decision-making costs.

Different types of collective decisions will have different gain and loss functions. To get more of a handle on which voting rule is optimal for which types of decisions, we need to assume something about these gains and losses. A simple way to approach this issue is to assume that the loss to someone on the losing side of an issue is proportional to the gain to a 
winner, $t=b s, b \geq 0$. It is then easy to show that the majority satisfying (4), $m^{*}$, increases with $b$. Some possibilities are illustrated in Figure 1. To the left of $m=0.5$, the outcome under a qualified majority rule is undefined as mutually inconsistent proposals can win, and so the $d^{\prime}(m)$ curve has only been drawn starting at $m=0.5$. For many categories of decisions the marginal gains lines are likely to resemble $g_{1}$ and $g_{2}$, and the simple majority rule will be optimal. For a high value of $b$, however, the marginal gains curve will look like $g_{3}$, and some qualified majority greater than 0.5 will be optimal. When the expected loss to the loser under a collective decision becomes very large relative to the gain to a winner, the marginal gains curve looks like $g_{4}$, and the unanimity rule becomes optimal. ${ }^{11}$

Consider first the simple action of wiggling one's toes. This action carries with it a small gain for the actor, and does no harm to anyone else. If the community had to vote on

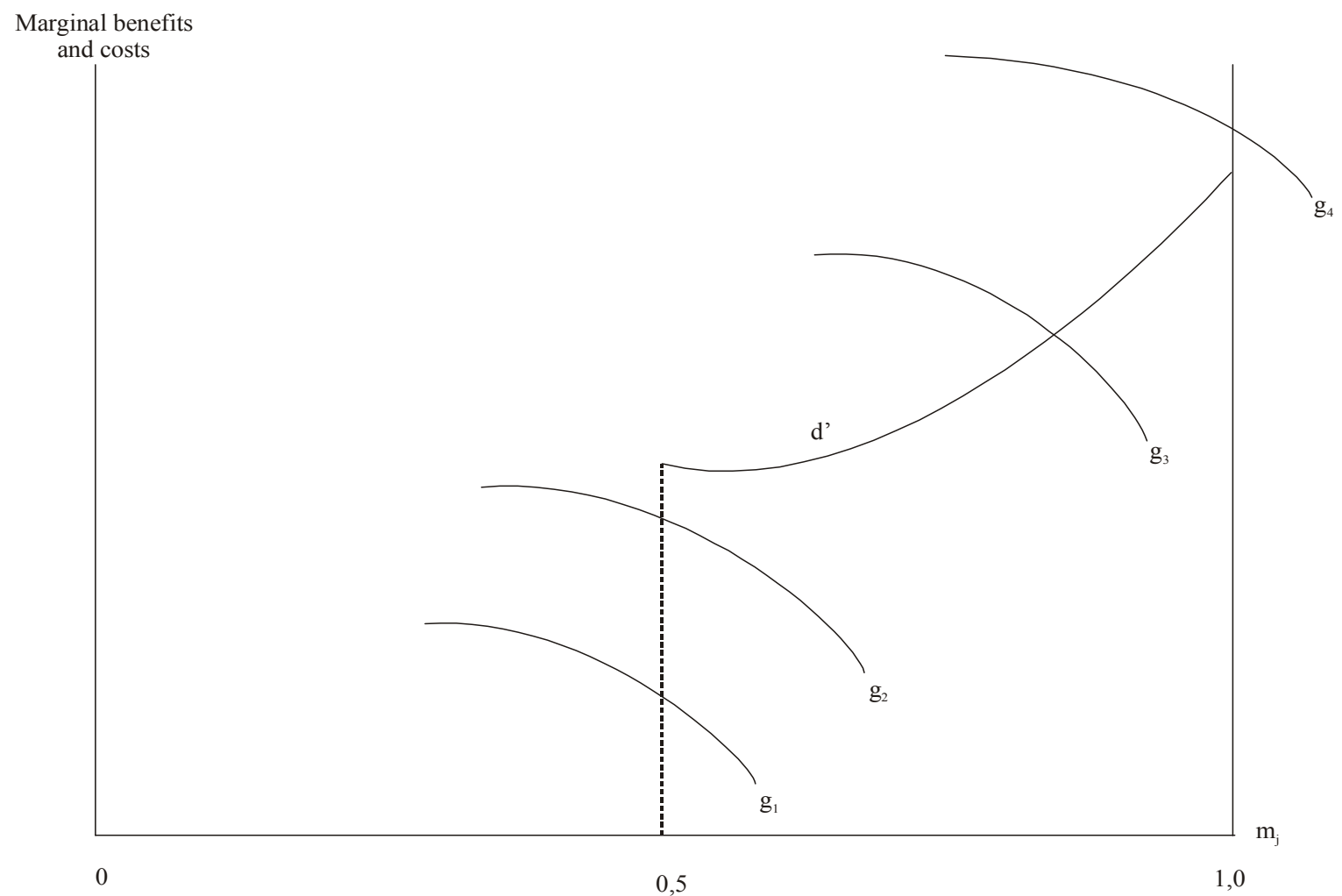


whether a person wishing to undertake this action should be allowed to do so or not, the simple majority rule would certainly be the optimal rule, and one assumes any proposal to allow someone to wiggle their toes would achieve the required majority, as no one has an incentive to vote against such a proposal. There are an infinite number of such actions giving a small utility gain to the actor at no loss to the community (wiggling one's ears, scratching one's toe, etc.), and thus the transaction costs of voting on all of them would be immense. Citizens at the constitutional convention would minimize future decision-making costs by allowing individuals to undertake any action that is not specifically prohibited.

When an action creates a negative externality, like say burning trash in an urban area, the community will want to be able to prohibit it, and thus the optimal constitution will allow future collective decisions to prohibit certain actions creating negative externalities. Trash burning might fall into the category of actions for which the simple majority rule is optimal.

Now consider the action of practicing one's religion. Religions often require their members to wear certain clothing, refrain from eating certain foods, or undertake other actions that, for whatever reasons, irritate some people in the community - that is religious practices sometimes create negative externalities. As such one must anticipate that at some time a majority of the community might choose to prohibit a religious practice of a minority, if this were possible under the simple majority rule. Such a collective action might be expected to impose a large loss in welfare on members of the religious minority, however. If the externality caused by the religious practice were modest, the characteristics of this collective action would fit those for which the unanimity rule is optimal. If all citizens at the constitutional stage perceived the loss from being prevented from practicing one's religion as very large relative to any loss to those experiencing a negative externality from this practice, and they were uncertain over whether they would be in the religious minority subject to a 
future prohibition, all citizens might well vote to protect the freedom to practice one's religion by requiring that any prohibitions of religious practices obtain the unanimous support of the community.

If those experiencing a loss of utility from a minority's religious practices were a large enough and rich enough group, they might be able to offer members of the minority a sufficiently large bribe that they would willingly give up the practice in question and a ban would pass even under the unanimity rule. But if the constitution drafters were correct in choosing religious practices as a set of actions to be prohibited only with unanimous agreement, i.e., the loss to those prevented from acting is very large relative to the externality it causes, any bribes offered are unlikely to be large enough to produce unanimity. When placing bans on religious practices under the protection of the unanimity rule, therefore, the constitution framers must anticipate that much time and energy will be wasted in future idle debates and votes on proposals to ban certain religious practices that in the end fail to achieve unanimity. Realizing this, the constitution framers can economize on future decision-making costs by placing a right to practice a religion into the constitution, whereby a constitutional right is defined as a prohibition against any person or group of persons - including the entire community - interfering with an individual's freedom to undertake the protected action.

Three features of constitutional rights under this theory need to be noted. First, explicit rights will be defined only for actions capable of generating sufficiently strong negative externalities to elicit efforts by some members of the community to restrict them. Even if wiggling one's toes gives great enjoyment, no constitutional protection in the form of an explicit right to act will be afforded, if it is unlikely that this action will ever generate a negative externality. Even actions that provide considerable benefits for the actor need not be protected, if they are not expected to be challenged. 
Second, there is an inherent tension between constitutional rights and the normative principles justifying majoritarian democracy. When the institutions of explicitly defined rights and the simple majority rule are both found in a constitution to deal with situations where individual interests conflict, these situations should differ dramatically in the perceived losses imposed on the different sides from curtailing the action. The simple majority rule is optimal for resolving a negative externality, when an individual at the constitutional stage expects the utility gain from undertaking the action to equal the loss it causes. Rights are defined precisely where the simple majority rule is not optimal, because the expected gains and losses from a ban are dramatically different, and the constitution framers wish to preclude its use. Because rights will be defined only when significant losses are expected for those prevented from acting relative to the losses imposed on others, disputes over rights are likely to be emotionally charged, as they pit a perhaps substantial majority that feels harmed by the action against an intense minority that benefits from it. ${ }^{12}$

Third, the kinds of constitutional rights defined by this theory are inherently relative, and thus they differ from many other definitions of rights, which see them as being absolute in some meaningful sense. In a community in which everyone is a member of the same religion, it may not occur to anyone that someone would ever challenge practicing this religion, and the constitution may, therefore, not explicitly protect religious freedom. If a country has suffered greatly under the dictatorial rule of a political party, it may choose after the dictatorship falls to ban the party and any books that defend this party or promote its ideology. In another country, which has never suffered under a dictatorship, such bans might be precluded by a constitutional right to "free speech." The nature of the actions explicitly protected as constitutional rights should vary across communities depending upon their own particular histories, the preferences (values) of their citizens, and their expectations of the 
future benefits and costs of allowing the actions.

\section{Defining Rights in the European Union}

There are essentially three questions that must be addressed with respect to rights within the EU. (1) Should there be rights defined at the European Union level? (2) If the answer to this question is yes, should they be the only rights in the EU or should member countries also be free to define their own sets of rights? (3) If rights are defined at both levels, to what extent should it be possible for EU-level rights to "trump" member country rights?

Rights are of importance only in communities with heterogeneous interests. A right to free speech becomes important only when there is disagreement among members of a community over what books should be allowed to be printed. The answers to our three questions depend once again upon the assumptions we make regarding the distribution of preferences across the EU and the nature of these preferences.

Assume to begin that the distribution of individual preferences across the EU is such as to justify a confederate structure for the EU - preferences are homogeneous within each country and differ across countries on at least some issues. It follows from the above discussion that individual member countries will wish to define different sets of rights. The answer to our second question is definitely yes, and the answer to the first is likely to be no. Consider, for example, rights involving habeas corpus protections. Such rights can be defended by the logic defined in the previous section, if at the time a constitution is written all citizens believe that a person held in jail without being charged and convicted of having committed a specific crime suffers a great loss relative to any possible negative externality that his release would impose on the rest of the community. The latter condition would 
require that the probability that this person would commit a crime if released would be relatively small, and the severity of any crime he committed would also be small. Now suppose that country $X$ contains a small terrorist group, which has for many years kidnaped and killed innocent citizens. In this country, the conditions needed to justify a right to be quickly charged and convicted of a crime to be held in prison may not be fulfilled. From behind a veil of ignorance all citizens may agree that the government should be allowed under certain circumstances, as say following several terrorist attacks, to arrest and detain suspected terrorists without charging them with particular crimes. Quite obviously in county $Y$, where no history of terrorism exists, citizens may feel quite differently and the constitution will contain a clause guaranteeing strong writ of habeas corpus protection. When preferences and circumstances differ across communities, no single set of rights is likely to be optimal for all.

It is of course possible with respect to a particular right that all citizens in all EU countries have the same preferences, even though they differ with respect to other rights issues. Even this situation does not require that the right in question be defined at the EU level rather than at the nation state level. Each member country can simply place the particular right in question into its own constitution, and all member country constitutions will be identical with respect to this right. This option is superior to defining a right at the EU level, given the assumption that preferences can differ across countries, because a time may come when the citizens of a country wish to redefine a particular right, and this would not be possible if it is defined at the EU level. Suppose, for example, that at one point in time citizens in each EU country decide to protect a person's "right to life" by prohibiting capital punishment. Following a series of terrorist assassinations, the citizens of $X$ reach the conclusion that their right to life would be better protected, if capital punishment were 
introduced for terrorist acts of murder. Even if one believes that the citizens of $X$ are misguided in their judgements about the deterrence effects of capital punishment, it does not seem justifiable that citizens in $Y$ and $Z$, where terrorism is not a problem, should be able to prevent citizens in $X$ from changing their constitution in a way that they believe will be to their benefit.

Constitutional rights at the EU level can be defended using the theory of rights outlined above, if we assume that individual preferences are distributed across Europe in such a way as to make a federalist structure optimal. Consider, for example, the right to practice a religion. Catholics are spread across Europe as are Protestants, Jews and members of other religions. Every European is aware that religious minorities have been discriminated against in the past, and can contemplate such discrimination in the future. There are two sets of assumptions under which this knowledge might lead a European to want to see a religious freedom right defined, and to prefer that it be defined at the EU level rather than in the country of which she is a citizen.

Assumption number one is that our European is sufficiently mobile that she can well imagine living in almost any of the EU countries sometime in the future. Today she lives in $Y$ where a majority of the citizens practice the same religion as she does, but tomorrow she may be living in $Z$ where her religion is in the minority, and she does not want to run the danger of religious persecution. Thus, EU-wide rights can be optimal when citizens with particular sets of preferences can be found across all of Europe, and Europeans are sufficiently mobile that they can imagine being in the minority at some future point in time. ${ }^{13}$ While the first rationalization of EU-wide rights rests on the assumption of real uncertainty about future positions, the second rests on the assumption of artificially imposed uncertainty. When contemplating what actions should receive rights protection, the 
European citizen steps behind a Rawlsian veil of ignorance and contemplates being a citizen of every other country. She does this not because she realistically expects to reside in another country, but as an ethical act. She contemplates being in the religious majority and being in a religious minority and wishes to protect people in the latter situation regardless of where they might live.

For this chain of reasoning to justify an EU-wide right, the European when she steps behind the veil of ignorance must contemplate being any other European and not just any other citizen of her nation state. Behind the veil of ignorance her answer to the question, "what are you?" must be "a European" and not "an Italian" or "a Venetian."14 The ethical European identifies first of all not with people of her nationality, but with all Europeans.

If either of these justifications for the existence of EU-level rights is accepted, so that the answer to the first question posed above becomes "yes," then the answer to the third question also is yes. The only justification for defining rights at the EU level is to be able to "trump" national and local majorities that may try to tyrannize over minorities in particular contexts. $^{15}$

\section{Citizen Rights within the European Union}

Before closing this paper, we shall pause to examine the situation as it pertains to citizen rights within the European Union today, and as may be the case under a new European Union Constitution.

Today a European Union citizen has two sets of rights - one defined in the constitution of the nation state of which she is a citizen, a second defined in the Convention for the Protection of Human Rights and Fundamental Freedoms. Adoption of Article 5 of the proposed first 16 articles of the Constitutional Treaty would make the Charter of 
Fundamental Rights of the European Union part of the EU Constitution and give an EU

citizen essentially three sets of constitutional rights. In this section we shall discuss the status and content of a citizen's rights at the European level. To save space we shall refer to the Convention for the Protection of Human Rights and Fundamental Freedoms as simply the Convention, and the Charter of Fundamental Rights of the European Union as the Charter.

\section{A. Citizen Rights under the Convention}

The Convention was first ratified by the members of the Council of Europe in 1950, and has been amended several times since. It contains 59 articles and is some 15 pages long, although only the first 18 articles (five plus pages) contain definitions of rights and freedoms, the remaining articles describe the European Court of Human Rights, which arbitrates the Convention, the procedures under which it operates, etc.

The rights defined under the Convention are in two senses subsidiary to those defined in the national constitutions. A citizen can seek satisfaction under the rights defined in the Convention only "after all domestic remedies have been exhausted" (Article 35). Thus, a citizen's rights are in the first instance those as defined in the constitution of the nation state which has granted him citizenship.

The second sense in which the Convention's rights are subsidiary to those of the nation states is that many of the rights defined by the Convention are conditional on their not being in conflict with a national law. For example, Article 2 states that, "No one shall be deprived of his life intentionally save in the execution of a sentence of a court following his conviction of a crime for which this penalty is provided by law" (emphasis added). Article 4 prohibiting slavery and forced labor explicitly exempts involuntary military service. Article 10 protects freedom of expression "subject to such formalities, conditions, restrictions or 
penalties as are prescribed by law and are necessary in a democratic society," and so on. Several of the articles of the Convention explicitly state that the protected freedom is conditional on it not having been curtailed by legislation at the national level, and thus these rights are relative in that sense.

When no such conditions are present in the defined right or they are not fulfilled, the rights defined at the national level are subsidiary to those defined in the Convention. Its final judgments are binding on the countries, which have accepted the convention. All current EU members have accepted the Convention.

\section{B. Citizen Rights under the Charter}

The Charter contains 54 articles devoted to defining rights and freedoms and runs to some 15 pages. An additional 83 pages of "notes" serves to explicate the meaning of the broad language contained in the Charter. Like many modern constitutions it is overly long and contains many articles in which the nature of the protection offered is ambiguous. Article 35, for example, ensures "a high level of human health protection," while Articles 37 and 38 ensure high levels of environmental and consumer protection. Article 33 offers the family "social protection."

Some of the articles are redundant or contradictory. Article 21, for example, states that, "Any discrimination based on any ground such as sex ... 16 additional criteria ... shall be prohibited." The first sentence of Article 23 goes on to ensure "equality between men and women." Such equality would, one would think, already have been ensured by the prohibition against discrimination on the grounds of sex contained in Article 21. Remarkably and contradictorily, the second sentence in Article 23 explicitly allows for discrimination on the grounds of sex, when it leads to "specific advantages in favour of the under-represented 
sex."

Some articles merely offer commentary or advice. The second provision under Article 12, for example, informs us that "Political parties at Union level contribute to expressing the political will of the citizens of the Union." A profound observation without doubt, but in what sense does it define a "fundamental right"?

Enough has been said to suggest to the reader that many of the articles of the Charter would not find support among large numbers of European citizens as currently drafted. Should the Charter's definitions of rights become binding on all citizens and countries, conflicts with local preferences and laws would seem inevitable. Unlike in the Convention many articles in the Charter do not explicitly defer to national laws and policies. Article 2 explicitly forbids capital punishment and thus would, presumably, preclude any country's introducing capital punishment for any type of crime, however serious. Article 5 prohibits slavery and forced labor and would, under a liberal interpretation, make conscription for military and civil service unconstitutional. Articles 11 and 12 ensuring freedoms of expression and association would, under a liberal interpretation, make Germany's and Austria's laws regarding the Nazi Party unconstitutional. Article 29 guaranteeing workers a right to strike would seem to preclude any country's passing a law against strikes by members of the police force. It is difficult to see how the long and broad set of rights defined in the Charter would not result in numerous conflicts with member countries over existing and future laws.

\section{Relationship between the Convention and the Charter}

The Charter was drafted by a special committee set up by the European Union and was signed by representatives on the European Parliament, the Council and the Commission 
in December of 2000. Article 2 of the draft of a new European Constitution, which appeared in the fall of 2002, leaves open the question of whether the Charter would merely be mentioned in the Constitution or would be included in full as a "bill of rights." Nevertheless, Article 2 proclaims "respect" for human rights as defined in both the Convention and the Charter. As we have seen, however, the nature of the rights defined in the two documents is often quite different. While the Convention would allow a country to introduce capital punishment, the Charter would forbid it. Which interpretation should be binding? The sweeping and often ambiguous language of the Charter would open the door for considerable constitutional disagreement over the status of both existing and future national laws. The adoption of the Charter as a binding part of a European Union Constitution would lay open the danger of continual legal strife between member countries and the Union, and of the eventual dismemberment of the Union.

\section{Conclusions}

The optimal criteria for defining citizenship and delineating citizens' rights in the EU rest crucially on the distribution of preferences within the EU. If the distribution of preferences justifies a confederate structure of the EU, as exists now, then rights should be delineated in the constitutions of the member countries, and no EU level rights should exist. Member countries should be free to impose strict conditions for obtaining citizenship even on citizens from other EU countries. Citizen rights defined at the EU level, on the other hand, can be defended, if one assumes (1) that individual preferences are dispersed across the EU, and thus every country contains people with similar preferences to the other countries, (2) that individuals within the EU are highly mobile, or (3) that they tend to identify first of all with other Europeans rather than people from their own countries, when making ethical 
choices.

Up to the present, mobility across borders within the EU has been surprisingly low, and few people in the EU seem to think of themselves as Europeans first and Swedes or Greeks second. These facts would seem to favor leaving definitions of citizenship and rights to the individual countries. As we have seen, the Charter defines numerous broad rights which, if they were liberally interpreted, would run afoul of current or potentially future actions by national parliaments. The continual assassinations by terrorists in Spain have led some people in that country to propose introducing the death penalty for terrorist murders. If Spain were to do so, and the Charter were part of a European Constitution, Spain would be in violation of the Constitution. Would the other EU countries expel Spain from the EU for such a violation? Would the EU be improved by such an expulsion?

The preamble to the Charter begins with the words "The peoples of Europe ...." In its second sentence, however, it goes on to proclaim the existence of universal values, which it intends to define in the Charter. The use of the word peoples suggests that Europe is made up of a heterogeneous mixture of different groups of people. Thus, the first two sentences of the Charter illustrate the tension between the heterogeneous nature of Europe, and the desire to impose homogeneous definitions of rights and citizenship.

The U.S. Constitution begins with the words "We the people of the United States..." Although it would have been common at the time of the Philadelphia Convention for people to think of themselves first of all as Virginians or Pennsylvanians and second of all as Americans, the drafters of the US Constitution recognized a degree of homogeneity among the colonists - forged by their common effort against England in the Revolutionary War that made it possible for them to think they were drafting a constitution for a people, rather than for a set of peoples. That the drafters of the Charter apparently perceived that they were 
drafting a document for a diverse collection of peoples should be cause for concern about the nature of the document.

A noticeable difference between the United States and Europe is that American politicians think of themselves as, and act to a greater degree as, servants of the citizens. If the citizens are concerned about crime, then the politicians pass tougher laws, and build more jails and gas chambers, regardless of "expert opinion" questioning the efficacy of such actions. In Europe, however, political leaders seem more often to believe that citizens ought to think and behave as the experts and politicians think that they should.

Recent election results in the Netherlands, France and other EU countries have revealed that the leaders of the major parties are greatly out of touch with the thinking of many voters regarding issues like immigration and crime. Large numbers of voters in these countries seem to have opinions on issues such as these that run against what has been defined by the elites of Europe as "politically correct." A similar danger looms with respect to a new constitution for the European Union.

The occasion of writing a new constitution might have seemed like the perfect opportunity to involve the citizens of Europe in "the European Union project" - an opportunity to correct "the democratic deficit" in the Union. The obvious way to accomplish this would have been to involve citizens in the process of convening the convention by, say, having them elect delegates to the convention. Instead, the delegation to the convention is a mixture of members of the political elite which already governs the EU (e.g., members of the Commission and the EU Parliament), and delegates chosen from the parliaments and governments of the member countries, delegates chosen in the same way that the members of the assembly that drafted the Charter were chosen - by the political elites of each country. Consequently, there was no direct participation by European citizens in the selection of the 
delegates, and most EU citizens undoubtedly have no knowledge of the identity of their representatives.

This method of selecting delegations is not unlike that used to select delegations from the colonies to the constitutional convention in Philadelphia in 1787. Perhaps the final document produced by the European Convention will be just as good or even better than the US Constitution. The task of the delegates in Philadelphia was made considerably easier by the absence of anti-federalists at the convention (Riker, 1987). Those who did attend were thus left free to replace a loose confederation of colonies with what would eventually become a tight federation of states. A disproportionately large fraction of the delegates at the convention in Belgium appear to be favorably disposed to a more centralized and federalist Union, and the first draft of the European constitution would move Europe a major step in this direction.

The adoption of the US Constitution led to a rapid "meltdown" of state sovereignty, as is illustrated by the following statement by a member of the First Congress. "Among the first sentiments expressed in the first Congress was that Virginia is no more. That Massachusetts is no [more], that Pennsylvania is no more, etc. We are now a nation of brethren" (quoted by Berns, 1988, p. 140). Enthusiasts for European integration also perhaps envisage a meltdown of state sovereignties should a constitution be adopted that creates a strong federalist structure. Even if such a constitution were adopted, however, it would be difficult to imagine the representatives at the first parliamentary session under the new constitution proclaiming, "Italy is no more. France is no more." The cultural differences across Europe today seem far greater than one imagines them having been in the American colonies at the end of the $18^{\text {th }}$ century. To neglect these differences when writing a new constitution for Europe is to court considerable conflict and an eventual unraveling of the 
whole enterprise.

\section{Endnotes}

1. The discussion in this section draws on Mueller (2002a).

2. Let $U_{B}$ and $U_{G}$ be the utilities that a Blue and Green experience if their preferred form of public good is provided, and $V_{B}$ and $V_{G}$ be the utilities that each experiences if the other group's preferred form is provided. Then sole citizenship for Blues is optimal from behind the veil of ignorance if $p U_{B}+(1-p) U_{G}>p V_{B}+(1-p) V_{G}$

where $p$ is the probability of being a Blue. If $p>1-p$, then this condition is satisfied when $U_{B}-V_{B}=V_{G}-U_{G}$.

3. Thus, the only way whites could dictate outcomes in South Africa was by denying blacks voting rights. Blacks, on the other hand, can dictate outcomes even when whites are allowed to vote under the simple majority rule.

4. Of course, one can have a liberal policy toward immigration and a stringent policy with respect to granting citizenship, as several EU countries have had, but I assume here that immigration will be greater, the more attractive it is, and granting citizenship under reasonable conditions is one way to increase the attractiveness of coming into the EU.

5. For further discussion of the costs and issues arising from citizen mobility, see Mueller (2003, Ch. 9).

6. It could be, of course, that individual preferences were homogeneous both within and across the member countries. No disagreements on EU policies would then arise, and all decisions could be made using the unanimity rule. There is considerable evidence against this being the case.

7. Draft of Articles 1 to 16 of the Constitutional Treaty, Brussels, February 6, 2003.

8. The classic reference here is, of course, Tiebout (1956). See also, Inman and Rubinfeld (1997) and Mueller (2003, Ch. 9).

9. For further discussion, see Mueller (1997, 2002b).

10. Specifically, I assume $p^{\prime}(m)>0, p^{\prime \prime}(m)<0$, and $(m=1) \leftrightarrow(p(m)=1)$.

11. The discussion to this point reproduces in a slightly different way the classic treatment of the choice of a voting rule by Buchanan and Tullock (1962, pp. 63-91). See also, Mueller (2001).

12. For further discussion of these issues, see either Mueller (1991) or Mueller (1996, Ch.14).

13. Note that having given sets of preferences dispersed across Europe does not suffice to justify EU-wide rights. A person with a particular set of preferences in a community in which he is in the majority has no reason to wish to define a right with respect to this set of preferences. Such a right becomes in his selfinterest only if he might leave the community.

14. The issue of how wide an individual's frame of reference will be I first discussed in Mueller (1974).

15. For a discussion of the constitutional trumps issue in the context of US federalism, see Gillette (1997). 


\section{References}

Berns, Walter. 1988. "The Writing of the Constitution of the United States," in Robert A. Goldwin and Art Kaufman, eds., Constitution Makers and Constitution Making, Washington DC: American Enterprise Institute, pp. 119-53.

Buchanan, James M. and Gordon Tullock, The Calculus of Consent, Ann Arbor: University of Michigan Press, 1962.

Gillette, Clayton P. 1997. "The Exercise of Trumps by Decentralized Governments," Virginia Law Review, 83, October, pp. 1347-1417.

Inman, Robert P. and Daniel L. Rubinfeld. 1997. "The Political Economy of Federalism," in Dennis C. Mueller, ed. Perspectives on Public Choice, Cambridge: Cambridge University Press, pp. 73-105.

Mueller, Dennis C. 1974. "Achieving the Just Polity," American Economic Review, 64, May, pp. 147-52.

Mueller, Dennis C. 1991. "Constitutional Rights,” Journal of Law, Economics, and Organization, 7, September, pp. 313-33.

Mueller, Dennis C. 1996. Constitutional Democracy, Oxford/New York: Oxford University Press.

Mueller, Dennis C. 1997. "Federalism and the European Union: A Constitutional Perspective" Public Choice, 90, pp. 255-80; reprinted in C.K. Rowley (ed.), Constitutional Political Economy in a Public Choice Perspective, Dordrecht: Kluwer.

Mueller, Dennis C. 2000. "Capitalism, Democracy and Rational Individual Behavior," Journal of Evolutionary Economics, 10, pp. 67-82

Mueller, Dennis C. 2001. "The Importance of Uncertainty in a Two-Stage Theory of Constitutions," Public Choice, 108, September, pp. 223-58.

Mueller, Dennis C. 2002a. "Defining Citizenship," Theoretical Inquiries in Law, 3, Jan., pp. 151-66.

Mueller, Dennis C. 2002b. "Constitutional Issues Regarding European Union Expansion," in Bernard Steunenberg, ed., Widening the European Union, London: Routledge, pp. 4157.

Mueller, Dennis C. 2003. Public Choice III, Cambridge: Cambridge University Press.

Riker, William H. 1987. “The Lessons of 1787,” Public Choice, 55, Sept., pp. 5-34.

Tiebout, Charles M. 1956. "A Pure Theory of Local Expenditures,” Journal of Political Economy, 64, Oct., pp. 416-24. 


\title{
CESifo Working Paper Series
}

\author{
(for full list see www.cesifo.de)
}

827 Geir B. Asheim, Green National Accounting for Welfare and Sustainability: A Taxonomy of Assumptions and Results, December 2002

828 Andrea Gebauer, Chang Woon Nam, and Rüdiger Parsche, Lessons of the 1999 Abolition of Intra-EU Duty Free Sales for Eastern European EU Candidates, December 2002

829 Giacomo Corneo, Work and Television, December 2002

830 Vivek H. Dehejia and Yiagadeesen Samy, Trade and Labour Standards - Theory, New Empirical Evidence, and Policy Implications, December 2002

831 Geir B. Asheim and Wolfgang Buchholz, A General Approach to Welfare Measurement through National Income Accounting, December 2002

832 Aaron Tornell and Frank Westermann, The Credit Channel in Middle Income Countries, January 2003

833 Gebhard Flaig, Time Series Properties of the German Monthly Production Index, January 2003

834 Campbell Leith and Jim Malley, Estimated Open Economy New Keynesian Phillips Curves for the G7, January 2003

835 Burkhard Heer and Bernd Süssmuth, Inflation and Wealth Distribution, January 2003

836 Erkki Koskela and Leopold von Thadden, Optimal Factor Taxation under Wage Bargaining - A Dynamic Perspective, January 2003

837 Carola Grün and Stephan Klasen, Growth, Income Distribution, and Well-Being: Comparisons across Space and Time, January 2003

838 Robert S. Chirinko and Ulf von Kalckreuth, On the German Monetary Transmission Mechanism: Interest Rate and Credit Channels for Investment Spending, January 2003

839 Sascha O. Becker, Andrea Ichino, and Giovanni Peri, How Large is the "Brain Drain" from Italy?", January 2003

840 Albert Berry and John Serieux, All About the Giants: Probing the Influences on Growth and Income Inequality at the End of the $20^{\text {th }}$ Century, January 2003

841 Robert Fenge and Martin Werding, Ageing and the Tax Implied in Public Pension Schemes: Simulations for Selected OECD Countries, January 2003 
842 Robert Fenge and Martin Werding, Ageing and Fiscal Imbalances Across Generations: Concepts of Measurement, January 2003

843 Giovanni Andrea Cornia, The Impact of Liberalisation and Globalisation on Income Inequality in Developing and Transitional Economies, January 2003

844 Peter Fredriksson and Per Johansson, Program Evaluation and Random Program Starts, January 2003

845 Bernd Hayo and Matthias Wrede, Fiscal Equalisation: Principles and an Application to the European Union, January 2003

846 Syed M. Ahsan and Jaideep Oberoi, Inequality, Well-being and Institutions in Latin America and the Caribbean, January 2003

847 Chang Woon Nam and Doina Maria Radulescu, The Role of Tax Depreciation for Investment Decisions: A Comparison of European Transition Countries, January 2003

848 V. Bhaskar and Steinar Holden, Wage Differentiation via Subsidised General Training, January 2003

849 Paloma Lopez-Garcia, Labour Market Performance and Start-up Costs: OECD Evidence, January 2003

850 Christian Keuschnigg and Soren Bo Nielsen, Public Policy for Start-up Entrepreneurship with Venture Capital and Bank Finance, January 2003

851 Yin-Wong Cheung, Menzie D. Chinn, and Eiji Fujii, China, Hong Kong, and Taiwan: A Quantitative Assessment of Real and Financial Integration, January 2003

852 Gregory D. Hess, The Economic Welfare Cost of Conflict: An Empirical Assessment, February 2003

853 Douglas J. Cumming and Jeffrey G. MacIntosh, Comparative Venture Capital Governance. Private versus Labour Sponsored Venture Capital Funds, February 2003

854 Eckhard Janeba and John Douglas Wilson, Decentralization and International Tax Competition, February 2003

855 Tapio Palokangas, Capital Accumulation and Employment Cycles in a Model of Creative Destruction, February 2003

856 Brendan Walsh, When Unemployment Disappears: Ireland in the 1990s, February 2003

857 Luis H. R. Alvarez and Erkki Koskela, A General Approach to the Stochastic Rotation Problem with Amenity Valuation, February 2003

858 Christian Schultz, Strategic Campaigns and Redistributive Politics, February 2003

859 Ernst Fehr and Joseph Henrich, Is Strong Reciprocity a Maladaptation? On the Evolutionary Foundations of Human Altruism, February 2003 
860 Haizhou Huang, Dalia Marin, and Chenggang Xu, Financial Crisis, Economic Recovery and Banking Development in Former Soviet Union Economies, February 2003

861 Pedro Cardoso and Bernard M.S. van Praag, How Sustainable Are Old-age Pensions in a Shrinking Population with Endogenous Labour Supply?, February 2003

862 Volker Meier, Efficient Transfer of Aging Provisions in Private Health Insurance, February 2003

863 Edward Castronova, Theory of the Avatar, February 2003

864 Robert S. Chirinko, Hans van Ees, Harry Garretsen, and Elmer Sterken, Investor Protections and Concentrated Ownership: Assessing Corporate Control Mechanisms in the Netherlands, February 2003

865 Bernard M.S. van Praag and Pedro Cardoso, The Mix Between Pay-as-you-go and Funded Pensions and what Demography has to do with it, February 2003

866 Ernst Fehr, Urs Fischbacher, Bernhard von Rosenbladt, Jürgen Schupp, and Gert G. Wagner, A Nation-Wide Laboratory. Examining Trust and Trustworthiness by Integrating Behavioral Experiments into Representative Survey, February 2003

867 Frank Heinemann, The Inflationary Impact of Wage Indexation, February 2003

868 Eytan Sheshinski, Bounded Rationality and Socially Optimal Limits on Choice in a Self-Selection Model, February 2003

869 M. Hashem Pesaran, Estimation and Inference in Large Heterogenous Panels with Cross Section Dependence, February 2003

870 Luis H. R. Alvarez and Erkki Koskela, On the Tree-Cutting Problem under Interest Rate and Forest Value Uncertainty, February 2003

871 Norbert Berthold and Rainer Fehn, Unemployment in Germany: Reasons and Remedies, February 2003

872 Clemens Fuest, Bernd Huber, and Philipp Tilleßen, Tax Policy and Entrepreneurship in the Presence of Asymmetric Information in Capital Markets, February 2003

873 Eytan Sheshinski, Optimum and Risk-Class Pricing of Annuities, February 2003

874 Willi Leibfritz, Paul O'Brien and Jean-Christophe Dumont, Effects of Immigration on Labour Markets and Government Budgets - An Overview, February 2003

875 M. Hashem Pesaran and Allan Timmermann, How Costly is it to Ignore Breaks when Forecasting the Direction of a Time Series?, February 2003

876 Thorvaldur Gylfason and Gylfi Zoega, Education, Social Equality and Economic Growth: A View of the Landscape, February 2003 
877 Robin Boadway and Jean-François Tremblay, Public Economics and Startup Entrepreneurs, February 2003

878 Erkki Koskela and Roope Uusitalo, The Un-Intended Convergence: How the Finnish Unemployment Reached the European Level, February 2003

879 Robert Fenge and Volker Meier, Pensions and Fertility Incentives, February 2003

880 Eytan Sheshinski, Note on Income Taxation and Occupational Choice, February 2003

881 A B Atkinson, Income Inequality in OECD Countries: Data and Explanations, February 2003

882 Thomas Gehrig and Rune Stenbacka, Venture Cycles: Theory and Evidence, February 2003

883 Ralf Becker and Thomas Hellmann, The Genesis of Venture Capital - Lessons from the German Experience, March 2003

884 Eytan Sheshinski, Note on the Optimum Pricing of Annuities, March 2003

885 Paul De Grauwe and Magdalena Polan, Globalisation and Social Spending, March 2003

886 F. van der Ploeg, Do Social Policies Harm Employment and Growth?, March 2003

887 Mirjam van Praag, Initial Capital Constraints Hinder Entrepreneurial Venture Performance: An empirical analysis, March 2003

888 Bernard Steunenberg, Coordinating Sectoral Policymaking: Searching for Countervailing Mechanisms in the EU Legislative Process, March 2003

889 Eytan Sheshinski, Optimum Delayed Retirement Credit, March 2003

890 Frederick van der Ploeg, Rolling Back the Public Sector - Differential effects on employment, investment and growth, March 2003

891 Paul De Grauwe and Marc-Alexandre Sénégas, Monetary Policy in EMU when the Transmission is Asymmetric and Uncertain, March 2003

892 Steffen Huck and Kai A. Konrad, Strategic Trade Policy and the Home Bias in Firm Ownership Structure, March 2003

893 Harry Flam, Turkey and the EU: Politics and Economics of Accession, March 2003

894 Mathias Hoffmann and Ronald MacDonald, A Re-examination of the Link between Real Exchange Rates and Real Interest Rate Differentials, March 2003

895 Badi H. Baltagi, Espen Bratberg, and Tor Helge Holmås, A Panel Data Study of Physicians' Labor Supply: The Case of Norway, March 2003

896 Dennis C. Mueller, Rights and Citizenship in the European Union, March 2003 